\title{
Packaging Design Criteria for the Type B Drum
}

\author{
W. S. Edwards \\ R. J. Smith
}

Consultant

A. H. Wells, Ph.D.

Date Published

September 1995

Prepared for the U.S. Department of Energy Assistant Secretary for Environmental Management

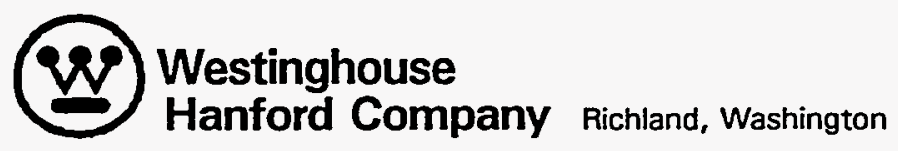

Management and Operations Contractor for the

U.S. Department of Energy under Contract DE-AC06-87RL10930 


\section{DISCLAIMER}

This report was prepared as an account of work sponsored by an agency of the United States Government. Neither the United States Government nor any agency thereof, nor any of their employees, make any warranty, express or implied, or assumes any legal liability or responsibility for the accuracy, completeness, or usefulness of any information, apparatus, product, or process disclosed, or represents that its use would not infringe privately owned rights. Reference herein to any specific commercial product, process, or service by trade name, trademark, manufacturer, or otherwise does not necessarily constitute or imply its endorsement, recommendation, or favoring by the United States Government or any agency thereof. The views and opinions of authors expressed herein do not necessarily state or reflect those of the United States Government or any agency thereof. 


\section{DISCLAIMER}

Portions of this document may be illegible in electronic image products. Images are produced from the best available original document. 


\section{CONTENTS}

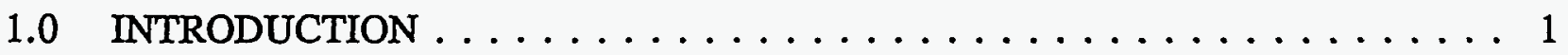

1.1 BACKGROUND $\ldots \ldots \ldots \ldots \ldots \ldots \ldots \ldots \ldots \ldots \ldots \ldots \ldots$

1.2 PURPOSE AND SCOPE $\ldots \ldots \ldots \ldots \ldots \ldots \ldots \ldots \ldots$

1.3 JUSTIFICATION $\ldots \ldots \ldots \ldots \ldots \ldots \ldots \ldots \ldots \ldots$

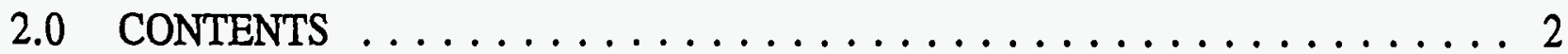

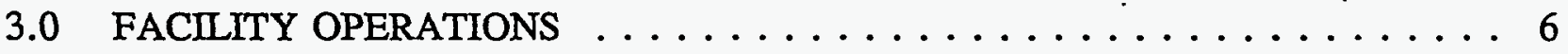

3.1 ORIGINATING FACILITY $\ldots \ldots \ldots \ldots \ldots \ldots \ldots \ldots \ldots \ldots \ldots \ldots$

3.2 RECEIVING FACILITY $\ldots \ldots \ldots \ldots \ldots \ldots \ldots \ldots \ldots$

4.0 PACKAGING/TRANSPORT SYSTEM DESIGN CRITERIA $\ldots \ldots \ldots \ldots \ldots 8$

4.1 GENERAL $\ldots \ldots \ldots \ldots \ldots \ldots \ldots \ldots \ldots \ldots \ldots \ldots \ldots$

4.2 TYPE B DRUM $\ldots \ldots \ldots \ldots \ldots \ldots \ldots \ldots \ldots \ldots$

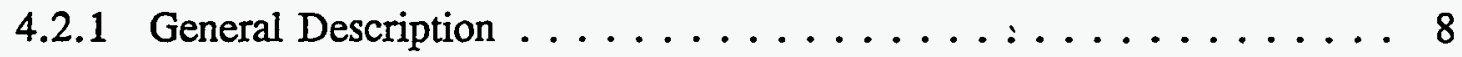

4.2 .2 Loading/Unloading $\ldots \ldots \ldots \ldots \ldots \ldots \ldots \ldots$

4.2 .3 Containment $\ldots \ldots \ldots \ldots \ldots \ldots \ldots \ldots \ldots \ldots$

4.2.4 Thermal . . . . . . . . . . . . . . . 9

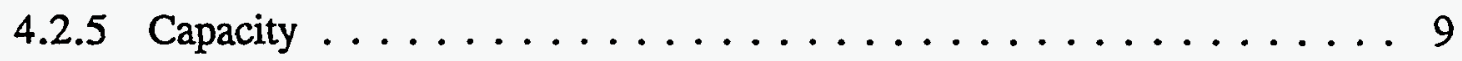

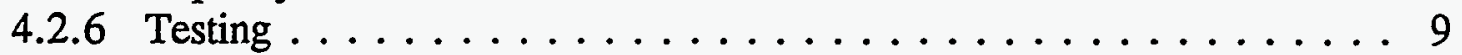

4.2 .7 Metric Units . . . . . . . . . . . . . . . 9

4.2 .8 Materials .................... 9

4.3 SYSTEM DESCRIPTION . . . . . . . . . . . . . . 9

4.3.1 System Components . . . . . . . . . . . . . 10

4.3.2 Shipping Configuration $\ldots \ldots \ldots \ldots \ldots \ldots \ldots \ldots \ldots$

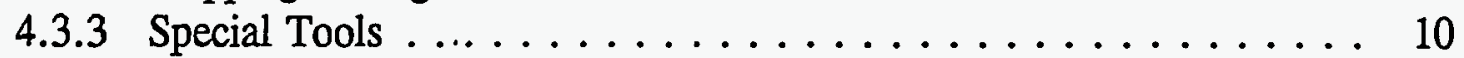

4.3 .4 Procedures $\ldots \ldots \ldots \ldots \ldots \ldots \ldots \ldots \ldots \ldots \ldots \ldots \ldots$

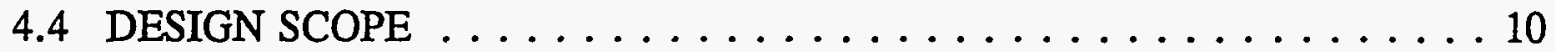

4.4.1 Design of the Type B Drum Package $\ldots \ldots \ldots \ldots \ldots \ldots \ldots$

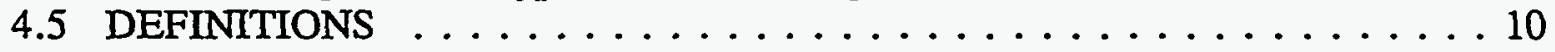

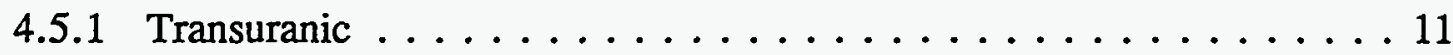

4.5.2 Containment Vessel . . . . . . . . . . . . . 11

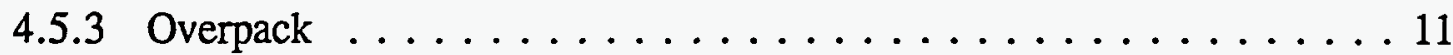

4.5.4 Gas Generation . . . . . . . . . . . . . . 11

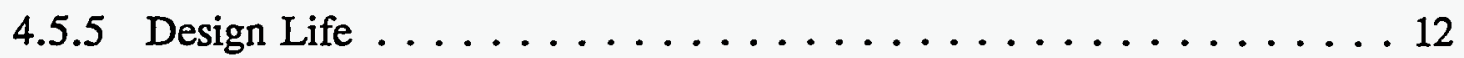

5.0 DESIGN BASIS ENVIRONMENT AND CONDITIONS $\ldots \ldots \ldots \ldots \ldots \ldots$

5.1 NORMAL CONDITIONS OF TRANSPORT $\ldots \ldots \ldots \ldots \ldots \ldots \ldots$

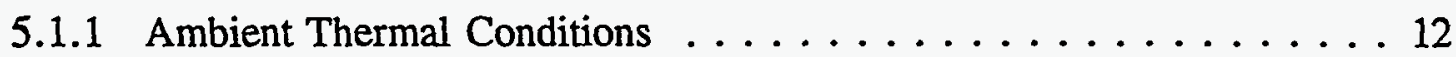

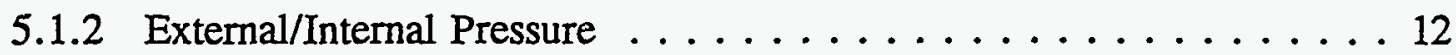

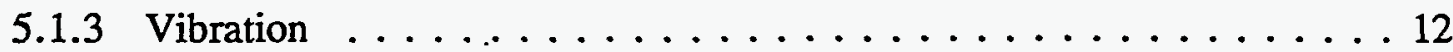

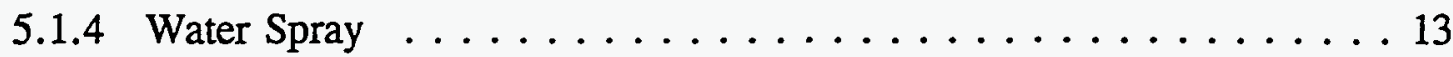


WHC-SP-1168 Rev. 0

CONTENTS (cont.)

5.1 .5 Free Drop . . . . . . . . . . . . . . 13

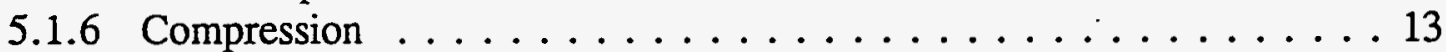

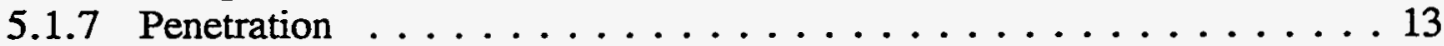

5.2 OTHER REGULATORY NORMAL CONDITION LOADS . . . . . . . 13

5.2 .1 Lifting Devices . . . . . . . . . . . . . 13

5.2 .2 Tie-Down Devices . . . . . . . . . . . . . . . . . 14

5.3 OTHER NORMAL LOADING CONDITIONS $\ldots \ldots \ldots \ldots \ldots \ldots$

5.3 .1 Handling Loads . . . . . . . . . . . . . . . . 14

5.3 .2 Fabrication Loads $\ldots \ldots \ldots \ldots \ldots \ldots \ldots \ldots \ldots$

5.3 .3 Test Condition Loads . . . . . . . . . . . . . . . . . . 14

5.3 .4 External Environmental Loads . . . . . . . . . . . . . 15

5.4 HYPOTHETICAL ACCIDENT CONDITIONS $\ldots \ldots \ldots \ldots \ldots \ldots$

5.4 .1 Nine-Meter Free Drop $\ldots \ldots \ldots \ldots \ldots \ldots \ldots \ldots$

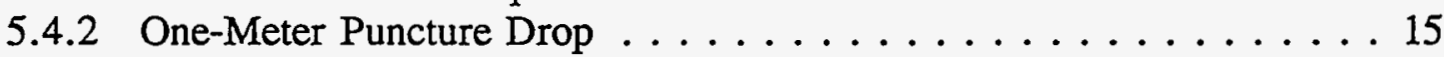

5.4 .3 Thermal . . . . . . . . . . . . . . 15

5.4 .4 Water Immersion . . . . . . . . . . . . . . . . 16

5.5 INTERNATIONAL ATOMIC ENERGY AGENCY CONDITIONS $\ldots \ldots \ldots 16$

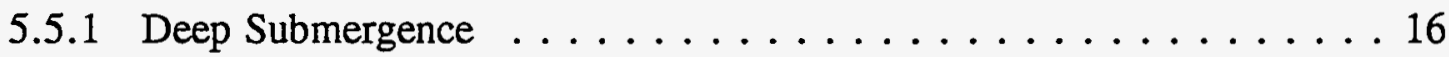

6.0 STRUCTURAL DESIGN CRITERIA . . . . . . . . . . . . . . . . . 16

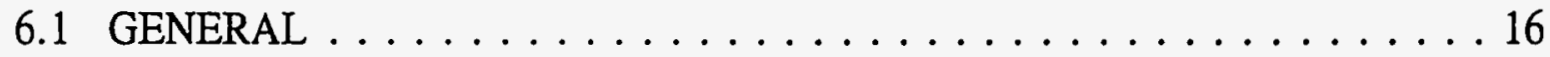

6.1 .1 Material Properties ................. 16

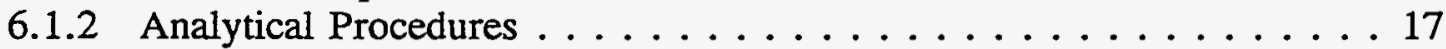

6.2 NORMAL LOAD CONDITIONS . . . . . . . . . . . . . 17

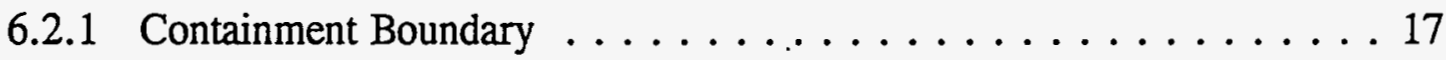

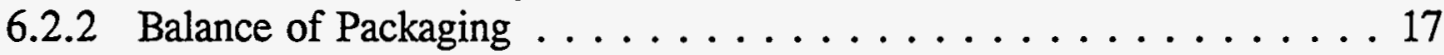

6.3 HYPOTHETICAL ACCIDENT CONDITIONS $\ldots \ldots \ldots \ldots \ldots \ldots$

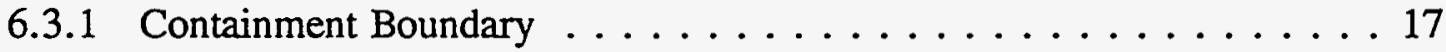

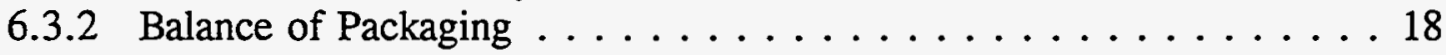

6.4 EXPERIMENTAL STRESS ANALYSIS $\ldots \ldots \ldots \ldots \ldots \ldots \ldots$

7.0 NUCLEAR DESIGN CRITERIA $\ldots \ldots \ldots \ldots \ldots \ldots \ldots \ldots \ldots$

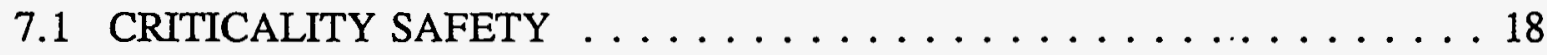

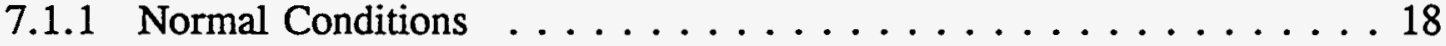

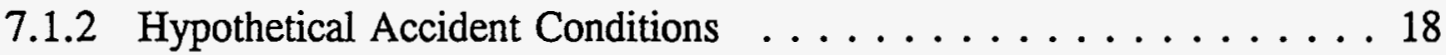

7.2 SHIELDING . . . . . . . . . . . . . . . . . . . 19

7.2 .1 Normal Conditions . . . . . . . . . . . . . . . . . 19

7.2.2 Hypothetical Accident Conditions . . . . . . . . . . 19

7.3 CONTAINMENT . . . . . . . . . . . . . . . . . . . . . 19

7.3 .1 Normal Conditions . . . . . . . . . . . . . . . 19

7.3.2 Hypothetical Accident Conditions . . . . . . . . . . . . 19 
WHC-SP-1168 Rev. 0

CONTENTS (cont.)

7.4 HEAT MANAGEMENT $\ldots \ldots \ldots \ldots \ldots \ldots \ldots \ldots \ldots \ldots \ldots \ldots$

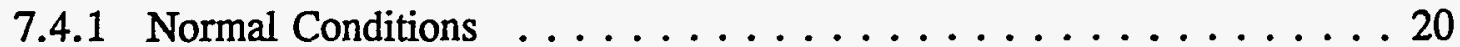

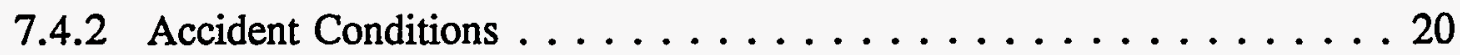

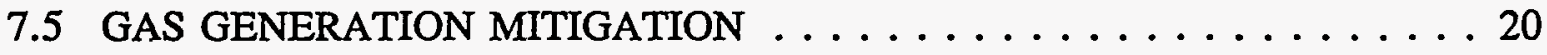

8.0 PACKAGE SERVICE REQUIREMENTS . . . . . . . . . . . . . . . 20

8.1 OPERATIONAL AND TRANSPORTATION INTERFACE

REQUIREMENTS . . . . . . . . . . . . . . . . 20

8.2 IN-SERVICE INSPECTION/MAINTENANCE REQUIREMENTS $\ldots \ldots 21$

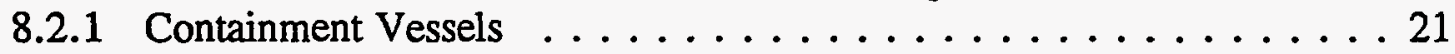

8.2 .2 Balance of Package . . . . . . . . . . . . . 21

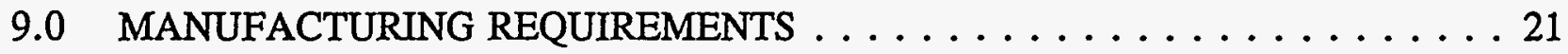

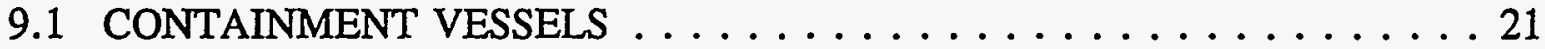

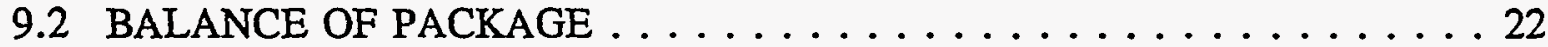

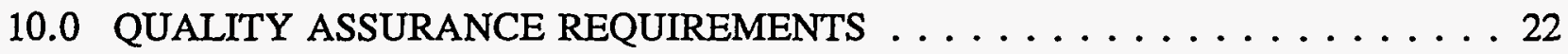

11.0 REFERENCES . . . . . . . . . . . . . . . . . . 23

\section{LIST OF TABLES}

I Summary of Rocky Flats Residues $\ldots \ldots \ldots \ldots \ldots \ldots$ 
WHC-SP-1168 Rev. 0

\section{LIST OF FIGURES}

$\begin{array}{ll}\text { ANSI } & \text { American National Standards Institute } \\ \text { ASME } & \text { American Society of Mechanical Engineers } \\ \text { DOE } & \text { U.S. Department of Energy } \\ \text { ICV } & \text { inner containment vessel } \\ \text { NRC } & \text { Nuclear Regulatory Commission } \\ \text { OCV } & \text { outer containment vessel } \\ \text { TRU } & \text { transuranic } \\ \text { WIPP } & \text { Waste Isolation Pilot Plant }\end{array}$


WHC-SP-1168 Rev. 0

\section{PACKAGING DESIGN CRITERIA FOR THE TYPE B DRUM}

\subsection{INTRODUCTION}

\subsection{BACKGROUND}

The Type B Drum package is a transportation cask capable of shipping a single 55-gal (208 L) drum of transuranic (TRU) waste. The Type B Drum is smaller than existing certified packages, such as the TRUPACT-II cask, but will allow payloads with higher thermal and gas generation rates, thus providing greater operational flexibility. The Type B Drum package has double containment so that plutonium contents and other radioactive material may be transported in Type B quantities. Conceptual designs of unshielded and shielded versions of the Type B Drum were completed in Report on the Conceptual Design of the Unshielded Type B Drum Packaging and Report on the Conceptual Design of the Shielded Type B Drum Packaging (WEC 1994a, WEC 1994b), which demonstrated the Type B Drum to be a viable packaging system.

A Type B package containment system must withstand the normal conditions of transport and the hypothetical accident conditions, which include a 9-m (30-ft) drop onto an unyielding surface and a $1-\mathrm{m}(3-\mathrm{ft})$ drop onto a $15-\mathrm{cm}(6-\mathrm{in}$.) diameter pin, and a fire and immersion scenarios.

\subsection{PURPOSE AND SCOPE}

The purpose and scope of this Packaging Design Criteria includes the following:

- Describe the Type B Drum and its proposed operation

- Define the payload proposed for the Type B Drum

- Establish the design requirements and safety analysis methodology for the Type B Drum.

\subsection{JUSTIFICATION}

The report, Backlog Residues at the DOE Rocky Flats Plant: Residue IDC Descriptions, Revision 1 (RFP 1993), states that Rocky Flats Environmental Technology Site currently possesses approximately $808 \mathrm{~m}^{3}(28,543 \mathrm{cu} \mathrm{ft})$ of plutonium residue, most of which can be shipped inside of Type B Drum. Residue is defined as plutonium-bearing material, which historically contained sufficient quantities of plutonium to warrant processing to recover plutonium. However, since operations at Rocky Flats have been terminated, this 
residue is now considered to be waste that will eventually be disposed. None of the plutonium residue that is currently stored at Rocky Flats can be shipped inside of existing packaging (such as the TRUPACT-II). In addition, there is a consent decree between the Colorado Department of Health and the U.S. Department of Energy (DOE) to remove all residue from Rocky Flats by January 1, 1999. The residue will have to be shipped to another DOE facility to be placed into a form suitable for disposal at the Waste Isolation Pilot Plant (WIPP). At present, no packaging exists that can ship this residue material on public highways, in accordance with U.S. Department of Transportation or Nuclear Regulatory Commission (NRC) requirements.

The DOE Office of Fissile Material Disposition is considering poisoning excess weapons-grade plutonium with gadolinium, vitrifying it, and placing the resulting ceramic pellets in drums for transport to its final disposal site. The Type B Drum will be able to safely transport greater quantities of ceramic pellets than any other existing packaging or packaging under development.

TRU waste will be shipped to WIPP or the Yucca Mountain Geologic Waste Repository in the TRUPACT-II transportation cask. TRUPACT-II is a Type B container that has been issued Certificate of Compliance Number USA/9218/B(U)F by the NRC, indicating compliance with the regulations of 10 CFR 71, "Packaging and Transportation of Radioactive Materials," Code of Federal Regulations, as amended. TRUPACT-II is a double-contained package that can transport up to 14 drums or 2 metal standard waste boxes per shipment. The use of TRUPACT-II is limited by worst-case analytic assumptions of gas generation, which impose a decay heat limitation that is lower than the package would otherwise require. Testing can be used instead to demonstrate that the actual gas generation rate of a given drum or standard waste box is sufficiently low to permit the raising of the heat limit for that container. Alternatively, a robust, small package for a single drum can provide a higher heat load (and a higher gas generation rate). Therefore, one of the purposes of this project is to develop a smaller, single drum package to supplement the TRUPACT-II package.

\subsection{CONTENTS}

The contents of the Type B Drum will be the residues at Rocky Flats, plutonium ceramic pellets, or TRU waste contents similar to the TRUPACT-II.

The residues at Rocky Flats, defined as plutonium bearing materials, have historically contained enough plutonium to warrant processing the materials to recover the plutonium. These residues came from production processes including component manufacture, laboratory and research development, and the plutonium recovery process itself. Table 1 shows the types of residues, the chemicals involved, the physical form, and the concentration of each. Detailed criticality, shielding, and gas generation analysis of each residue category will be required before they can be shipped within the Type B Drum, but it is expected that most residue material will be acceptable. 
Table 1. Summary of Rocky Flats Residues. (2 sheets)

\begin{tabular}{|c|c|c|c|}
\hline $\begin{array}{l}\text { Residue group } \\
\text { types }\end{array}$ & Chemicals description & Physical form & Concentration \\
\hline Oxides & $\begin{array}{l}\text { High levels of americium \& other tracer } \\
\text { elements }\end{array}$ & $\begin{array}{l}\text { Fine powder ( } 1 \text { to } \\
25 \text { microns) }\end{array}$ & Upon request from Rocky Flats \\
\hline Fluorides & $\begin{array}{l}\text { Plutonium tetrafluoride - high neutron } \\
\text { emitter }\end{array}$ & $\begin{array}{l}\text { Powder form - pink } \\
\text { cake }\end{array}$ & Upon request from Rocky Flats \\
\hline Ash & $\begin{array}{l}\text { Carbon, silica, } \mathrm{Al} 2 \mathrm{O} 3, \mathrm{CaO}, \mathrm{Fe} 2 \mathrm{O} 3 \text {, } \\
\mathrm{Na} 2 \mathrm{O}\end{array}$ & $\begin{array}{l}\text { PVC, polyethylene, } \\
\text { paper, liquid, rubber, } \\
\text { filters with carbon, } \\
\text { metal, wood, fine } \\
\text { particulates }\end{array}$ & $\begin{array}{l}1.8-7 \% \mathrm{Pu} / \text { bulk wt. }(\approx 93 \% \text { of bulk } \\
\text { material has assay of } 7 \% \mathrm{Pu})\end{array}$ \\
\hline Salts & $\begin{array}{l}\text { Sodium chloride, magnesium chloride, } \\
\text { potassium chloride, zinc chloride, } \\
\text { calcium chloride, plutonium chloride, } \\
\text { calcium metal }\end{array}$ & $\begin{array}{l}\text { Dry, fused salts in } \\
\text { the form of chunks }\end{array}$ & $\begin{array}{l}0.5-80 \% \mathrm{Pu} / \text { bulk wt. }(\approx 0.2 \% \text { of bulk } \\
\text { material has assay of } 80 \% \mathrm{Pu} ; 84 \% \text { of } \\
\text { bulk material has assay of } 2.3- \\
6.5 \% \mathrm{Pu})\end{array}$ \\
\hline $\begin{array}{l}\text { Pyrochemical } \\
\text { Metals }\end{array}$ & Calcium metal, calcium-gallium & Salt & $\begin{array}{l}6.5-10.5 \% \mathrm{Pu} / \text { bulk wt. }(\approx 90 \% \text { of bulk } \\
\text { material has assay of } 6.1 \% \mathrm{Pu})\end{array}$ \\
\hline $\begin{array}{l}\text { Sand, Slag, and } \\
\text { Crucible }\end{array}$ & $\begin{array}{l}\text { Magnesium oxide, calcium fluoride, } \\
\text { calcium metal, uncoalesced plutonium } \\
\text { metal, pyrotechnic initiator, plutonium } \\
\text { fluoride }\end{array}$ & $\begin{array}{l}\text { Coarse pieces, } \\
\text { pulverized material, } \\
\text { chunks of crucible, } \\
\text { sand }\end{array}$ & $\begin{array}{l}0.6-44.4 \% \mathrm{Pu} / \text { bulk wt. }(\approx 98 \% \text { of bulk } \\
\text { material has assay of } 0.6-5.2 \% \mathrm{Pu})\end{array}$ \\
\hline Heels & $\begin{array}{l}\text { High concentrations of carbon, aluminum } \\
\text { magnesium oxide }\end{array}$ & Fine particulate & $\begin{array}{l}1.8-3.0 \% \mathrm{Pu} / \text { bulk wt. }(\approx 99.6 \% \text { of } \\
\text { bulk material has assay of } 3 \% \mathrm{Pu})\end{array}$ \\
\hline Combustibles & & $\begin{array}{l}\text { Paper wipes, plastics, } \\
\text { personal protective } \\
\text { equipment, rags, } \\
\text { rubber, teflon, PVC }\end{array}$ & $0.5 \% \mathrm{Pu} /$ bulk wt. \\
\hline
\end{tabular}


Table 1. Summary of Rocky Flats Residues. (2 sheets)

\begin{tabular}{|c|c|c|c|}
\hline $\begin{array}{l}\text { Residue group } \\
\text { types }\end{array}$ & Chemicals description & Physical form & Concentration \\
\hline Filters & & $\begin{array}{l}\text { Glass fibers and } \\
\text { corrugated aluminum } \\
\text { foil, wood, steel }\end{array}$ & $\begin{array}{l}1.0-4.3 \% \mathrm{Pu} / \text { bulk wt. }(\approx 64 \% \text { of bulk } \\
\text { material has assay of } 1 \% \mathrm{Pu})\end{array}$ \\
\hline Metal & $\begin{array}{l}\text { Stainless steel, aluminum, copper, iron, } \\
\text { tantalum, tungsten, platinum, lead }\end{array}$ & $\begin{array}{l}\text { Tools, piping, pieces } \\
\text { of equipment }\end{array}$ & $\begin{array}{l}0.2-0.9 \% \mathrm{Pu} / \text { bulk wt. }(\approx 33 \% \text { of bulk } \\
\text { material has assay of } 0.9 \% \mathrm{Pu})\end{array}$ \\
\hline Graphite & $\begin{array}{l}\text { Graphite, calcium fluoride, calcium, } \\
\text { magnesium }\end{array}$ & $\begin{array}{l}\text { Pure graphite pieces, } \\
\text { fine particulate }\end{array}$ & $\begin{array}{l}0.1-7.8 \% \mathrm{Pu} / \text { bulk wt. }(\approx 5 \% \text { of bulk } \\
\text { material has assay of } 7.8 \% \mathrm{Pu})\end{array}$ \\
\hline Firebrick & $\begin{array}{l}\text { High density alumina ceramic, actinide } \\
\text { oxide }\end{array}$ & Bricks & $\begin{array}{l}0.7-4.7 \% \mathrm{Pu} / \text { bulk wt. }(\approx 90 \% \text { of bulk } \\
\text { material has assay of } 0.7-1.2 \% \mathrm{Pu})\end{array}$ \\
\hline Sludge & Actinide concentrations & $\begin{array}{l}\text { Damp mass (paste), } \\
\text { dried and may } \\
\text { contain fines }\end{array}$ & $\begin{array}{l}3.4-7.6 \% \mathrm{Pu} / \text { bulk wt. }(\approx 85 \% \text { of bulk } \\
\text { material has assay of } 3.4-3.9 \% \mathrm{Pu})\end{array}$ \\
\hline Dirt/Blacktop & One drum of blacktop & $\begin{array}{l}\text { Blacktop, concrete, } \\
\text { dirt, sand }\end{array}$ & $0.1 \% \mathrm{Pu} /$ bulk wt. \\
\hline $\begin{array}{l}\text { Ceramic } \\
\text { Crucibles }\end{array}$ & $\begin{array}{l}\text { Magnesium oxide, pyrochemical salts, } \\
\text { aluminum silicate }\end{array}$ & $\begin{array}{l}\text { Intact crucibles to } \\
\text { broken chunks }\end{array}$ & $\begin{array}{l}1.7-2.7 \% \mathrm{Pu} / \text { bulk wt. ( } \approx 18 \% \text { of bulk } \\
\text { material has assay of } 2.7 \% \mathrm{Pu} \text {; rest is } \\
1.7 \% \mathrm{Pu})\end{array}$ \\
\hline
\end{tabular}


The plutonium ceramic pellets stem from the Fissile Materials Disposition Program. This program plans to produce $1.0 \%$ plutonium-loaded ceramic pellets containing gadolinium for neutron poisoning. The pellets will have a $2.5 \mathrm{~cm}$ (1.0 in) diameter, have a density of $4.5 \mathrm{~g} / \mathrm{cm}^{3}$, weigh $34.32 \mathrm{~g}(0.0076 \mathrm{lb})$, and contain $0.3 \mathrm{~g}$ of plutonium. The Fissile Materials Disposition Program prefers 55-gal drums fully loaded with pellets, which translates to 16,100 pellets per drum with a total pellet weight of $555 \mathrm{~kg}(1,221 \mathrm{lb})$ and a total plutonium weight of $5.55 \mathrm{~kg}(12.21 \mathrm{lb})$. The Fissile Materials Disposition Program will accept fewer pellets per 55-gal drum, if that reduction is required to meet shipping requirements. Detailed criticality calculations will be required before the maximum pellet loading per Type B Drum and fissile classification can be established.

TRU waste containers fall into one of two categories based on their hydrogen gas generation potential: Analytic category waste or test category waste. In the Safety Analysis Report for the TRUPACT-II Shipping Package, Revision 5 (Vectra 1994), theoretical worst-case calculations were performed to determine which waste containers could be shown to meet the limits on hydrogen concentration and could, therefore, be shipped without the need for testing. These theoretical worst-case calculations use bounding $\mathrm{G}$ values, which are a measure of the amount of hydrogen that can be generated by radiolysis of the waste materials. The waste containers that can be shipped without the need for testing comprise the analytical category. Because the primary mechanism for hydrogen gas generation is radiolysis, the limit on the hydrogen concentration for the analytic category is met by imposing a limit on the decay heat (or wattage) of the contents of the payload containers. A derivative limit on radiation source (alpha) is also thus imposed because alphas are the primary source of heat. The radioactive material content of the drum is thus limited for gas generation purposes, as well as for nuclear criticality and shielding purposes.

Decay heat limits for the waste containers are summarized in Tables 6-1, 6-2, and 6-3 of the TRUPACT-II Content Codes (TRUCON) (WIPP 1989) document. TRU waste materials may be classified into four waste types based on their chemical and physical characteristics as follows:

- I - Solidified Inorganics

- II - Solid Inorganics

- III - Solid Organics

- IV - Solidified Organics

Waste containers that exceed applicable decay heat limits belong in the test category, because they must be tested to determine the actual rate of gas generation and hydrogen concentration before shipment. Because the decay heat calculations for the analytic category are based on theoretical worst-case assumptions, it is probable that a significant number of containers of test category waste may be shippable after testing. In addition, a bounding $G$ value has not been established that belong to Waste Type IV, or Solidified Organics. All of the waste containers in this waste type belong to the test category, because an upper bound for their gas generation potential has not been established. 
The large capacity (14 drums, stacked in 2 levels of 7 each, or 2 standard waste boxes) of the TRUPACT-II transport cask causes heat that is generated within the containers to build up and produce higher temperatures than would occur if the containers were individually transported. The surface-to-volume ratio of a smaller package designed to transport a single TRU drum would be greater numerically than TRUPACT-II's ratio, and produce a better cooling effect. This would reduce the contribution to the gas generation caused by thermolysis. The interior space of the Type B Drum package can also be increased relative to the drum volume to produce a dilution effect greater than that of TRUPACT-II. These effects reduce the packing efficiency of Type B Drum relative to TRUPACT-II, but allow a higher heat and gas generation rate limit. In addition, the size and weight of the TRUPACT-II exceed the capabilities of some facilities, and a smaller package can be handled in any facility.

Package contents limits will be maximized without compromising facility access. The number of Type B Drums that may be shipped on a single legal weight truck will be derived from Type B Drum size and weight (i.e., the number of packages which may be transported simultaneously is not a specification).

The following are the package limits:

- Drum size - 55-Gal drum

- Drum weight - not to exceed $555 \mathrm{~kg}(1,221 \mathrm{lb})$ for $55-\mathrm{Gal}$ drum

- Drum dimensions - 55-Gal Drum, $61 \mathrm{~cm}$ diameter (24 in.) by $89 \mathrm{~cm}$ height (35 in.)

- Fissile material - to be determined by detailed analysis

- Flammable organics - not to exceed $500 \mathrm{ppm}$ in the headspace of a 55-gal drum

- Free liquids - not to exceed $1 \%$ by volume

- Prohibited materials - explosives, corrosives, nonradioactive pyrophorics, and pressurized containers. 


\subsection{FACILITY OPERATIONS}

\subsection{ORIGINATING FACILITY}

The originating facility will vary from within the DOE sites. The primary application of this package will be from users at the following sites.

- Rocky Flats Environmental Technology Site for shipment of plutonium residue material.

- Vitrification plant that produces ceramic plutonium pellets.

- Facilities that slowly accumulate small quantities of radioactive materials over a long period of time, such as laboratories.

- Generating, processing, or storage facilities making shipments of Type B waste.

- Waste retrieval project sites where further handling of the recovered drum may be prohibited and/or the characterization of the contents is uncertain.

- Sites where handling/emergency response teams require an overpack for a damaged or leaking drum.

\subsection{RECEIVING FACILITY}

As noted in the following, the receiving facility will vary depending upon the location and purpose of the site.

- Interim storage facilities that are permitted to receive and store TRU wastes or plutonium residue.

Note: current laws do not allow the construction of interim storage facilities for TRU wastes.

- The WIPP is intended to receive a limited quantity of TRU wastes for permanent geologic disposal in a salt formation near Carlsbad, New Mexico.

- A geologic repository is under development at the Yucca Mountain site in New Mexico for the permanent geological disposal of spent fuel and TRU wastes in a volcanic tuff deposit.

- The Deep Borehole Disposal Facility is intended to receive vitrified ceramic plutonium pellets. 
WHC-SP-1168 Rev. 0

\subsection{PACKAGING/TRANSPORT SYSTEM DESIGN CRITERIA}

\subsection{GENERAL}

The Type B Drum consists of the following major components:

- Drum - 55-gal drum with contents

- Inner and outer containments (double containment)

- Impact limiter (foam or crushable material)

- Shielding (dependent upon maximum radiation level of contents).

\subsection{TYPE B DRUM}

\subsubsection{General Description}

The package will permit the shipment of single drums while providing a double-containment option. The package is to have interchangeable parts to accommodate single- and double-containment shipments.

\subsubsection{Loading/Unloading}

The Type B Drum will be loaded in facilities that do not possess extensive crane or handling capabilities. The package will be capable of being loaded vertically. The loaded Type B Drum must be capable of movement via forklift or crane.

\subsubsection{Containment}

The Type B Drum is a package for the shipment of transuranic materials including plutonium and americium. The package will provide double containment, with leak tight seals helium leak tested to $10^{-7} \mathrm{std}-\mathrm{cm}^{3} / \mathrm{sec}$ during factory acceptance and maintenance testing. Containment seals will be tested to a sensitivity equivalent to a helium leak rate of $10^{-3} \mathrm{std}-\mathrm{cm}^{3} / \mathrm{sec}$ before each shipment. Testing procedures will be in conformance with American National Standards Institute (ANSI) Standard N14.5, Radioactive Materials Leakage Tests on Packages for Shipment (ANSI 1987). 


\subsubsection{Thermal}

The thermal limits of the Type B Drum will be maximized to provide the greatest operational flexibility possible. The conceptual design activities (WEC 1994a, 1994b) calculated that the Type B Drum could ship material that generates a minimum of $40 \mathrm{~W}$.

\subsubsection{Capacity}

The capacity of the Type B Drum is a single 55-gal TRU drum.

\subsubsection{Testing}

Drop testing is required to demonstrate compliance with the 9-m (30-ft) free drop and pin puncture requirements of 10 CFR 71 . Compliance with thermal, radiological, criticality safety, and other mechanical requirements of 10 CFR 71 will be demonstrated through analysis.

\subsubsection{Metric Units}

The design will be described with metric units and English equivalents. Items that are not commonly available in metric sizes may be based upon English units. English units may be used for stainless steel plate used to fabricate the Type B Drum package containment shells, with equivalent metric thicknesses also provided.

\subsubsection{Materials}

Outer and inner containment vessels will be fabricated from corrosion resistant austenitic stainless steel and conform to the American Society of Mechanical Engineers (ASME) Boiler and Pressure Vessel Code, Section III, Part D (ASME 1989). Materials will be compatible and will not cause galvanic corrosion.

\subsection{SYSTEM DESCRIPTION}

The configuration of the package system includes all items, tools, and processes required to perform the function of shipment of TRU drums. 
WHC-SP-1168 Rev. 0

\subsubsection{System Components}

The Type B Drum package is generally considered to be comprised of an inner containment and an outer containment, plus any shock absorbing outer packaging such as foam.

\subsubsection{Shipping Configuration}

The Type B Drum will be shipped vertically in a sole use truck.

\subsubsection{Special Tools}

Any special tools that must be used to load or unload the container are considered to be a part of the cask system. Special tools will be minimized.

\subsubsection{Procedures}

The procedures that are to be used to operate the package including loading, unloading, and decontamination must be provided in sufficient detail as to allow interfaces with facilities to be evaluated. Procedures for acceptance testing of newly fabricated components and maintenance are also required.

\subsection{DESIGN SCOPE}

The deliverable items for this project include the descriptions in Section 4.4.1.

\subsubsection{Design of the Type B Drum Package}

The design must be complete and evaluated to demonstrate compliance with the requirements of $10 \mathrm{CFR} 71$. The results of the evaluations are to be provided in the form of a safety analysis report for packaging. 


\subsection{DEFINITIONS}

\subsubsection{Transuranic}

Transuranic materials consist of waste that contains isotopes of plutonium, americium, or other element heavier than uranium. Quantities in excess of $20 \mathrm{Ci}$ of plutonium (the limit for Type A containers) must be transported in a Type B package.

\subsubsection{Containment Vessel}

The containment vessel is the structure that retains the contents of the package (payload) and prevents leakage of radioactive material at rates in excess of the requirements of 10 CFR 71.51. Double containment is provided by two independent vessels that do not share common structural components. The containment vessel(s) may require protection during the transportation phase to satisfy the requirements of 10 CFR 71.73.

Double containment is required, consisting of an inner containment vessel (ICV) and an outer containment vessel (OCV). The inner package must be removable from the outer container after a worst-case, 9-m (30-ft) drop and pin puncture. Deformation of the ICV and OCV must not be sufficient to bind the containment vessels together so that excessive force is required to separate them after a 9-m (30-ft) drop and pin puncture.

\subsubsection{Overpack}

The containment vessels may be protected during the 9-m (30-ft) drop and pin puncture events by energy-absorbing materials. If such materials are employed, then their effect upon package heat transfer must be evaluated.

\subsubsection{Gas Generation}

Hydrogen gas is generated by radiolysis of water contained within the contents and by radiolysis or thermolysis of packing materials (e.g., plastic bags). The limit for hydrogen gas within the package is $5.0 \%$ by volume in a 60 -day shipping period, as required by NRC Information Notice 85-72, Conditions for Waste Shipping Subject to Hydrogen Gas Generation (NRC 1984). 


\subsubsection{Design Life}

The package will be designed for a 40-yr design life. All components of the package will be designed to a 40-yr design life or will be replaceable. The package will be capable of being decommissioned at the end of its useful life without using cleaning fluids, which contain hazardous materials that could generate a mixed waste.

\subsection{DESIGN BASIS ENVIRONMENT AND CONDITIONS}

\subsection{NORMAL CONDITIONS OF TRANSPORT}

Normal conditions of transport are described in 10 CFR 71.71. Specific information regarding the Type B Drum are provided in this section.

\subsubsection{Ambient Thermal Conditions}

The maximum ambient temperature for normal operation is $38^{\circ} \mathrm{C}\left(100^{\circ} \mathrm{F}\right)$, with full solar insolence. The exterior conditions, plus the $40 \mathrm{w}$ generated by the waste contents of the package, will not result in excessive internal temperatures within the waste. Such excessive internal temperatures could result in a substantial contribution to gas generation through thermolysis. The minimum ambient temperature is $-40 \mathrm{C}^{\circ}\left(-40 \mathrm{~F}^{\circ}\right)$ for evaluation of seals, including the effects of still air and shade. The minimum ambient temperature for evaluation of structural performance is $-29^{\circ} \mathrm{C}\left(-20^{\circ} \mathrm{F}\right)$. Minimum and maximum decay heat conditions will be selected to maximize the effect on the package. Active cooling may not be employed.

\subsubsection{External/Internal Pressure}

Package evaluations will consider an external pressure reduced to $24.5 \mathrm{kPa}(3.5 \mathrm{psi})$ absolute and an external pressure increased to $140 \mathrm{kPa}(20 \mathrm{psi})$ absolute. The maximum design internal pressure for the package will not exceed $689 \mathrm{kPa}(100 \mathrm{psig})$.

\subsubsection{Vibration}

Package evaluation will consider vibration normally incident to truck traffic. The vibration standards are contained in ANSI Standard N14.23 Design Basis for Resistance to Shock and Vibration of Radioactive Material Packages Greater than One Ton in Truck Transport (ANSI 1994). 


\subsubsection{Water Spray}

The package will be analyzed for the effects of water spray that simulates exposure to rainfall of approximately $5 \mathrm{~cm} \mathrm{(2} \mathrm{in.)} \mathrm{per} \mathrm{hour} \mathrm{for} \mathrm{one} \mathrm{hour.}$

\subsubsection{Free Drop}

The effects of a normal operation free drop onto the package end, side, and corner will be considered. The drop will be onto a flat, unyielding horizontal surface and package orientation will be such that maximum damage occurs. The effects of the normal operation free drop may be evaluated through analysis or physical testing.

\subsubsection{Compression}

If the package weighs up to $5,000 \mathrm{~kg}(11,000 \mathrm{lb})$ loaded, it will be subject to a compression test simulating package stacking. The test will consist of the greater of either the equivalent of five times the package weight or the equivalent of $12.75 \mathrm{kPa}(1.85 \mathrm{psi})$ multiplied by the projected area of the package. The load will be applied for 24 hours uniformly to the package top and bottom, in the orientation of transport.

\subsubsection{Penetration}

The package will be subject to the impact of the hemispherical end of a vertical steel cylinder of $3.2 \mathrm{~cm}(1.25 \mathrm{in}$.) diameter and $6 \mathrm{~kg}(13 \mathrm{lb})$ mass, dropped from the height of $1 \mathrm{~m}$ (40 in.) onto the exposed surface of the package that is expected to be most vulnerable to puncture. The long axis of the cylinder must be perpendicular to the surface of the package.

\subsection{OTHER REGULATORY NORMAL CONDITION LOADS}

\subsubsection{Lifting Devices}

If routine operations specify the use of conventional slings or chains for package lifting, then these items will have a minimum safety factor of 5 based on breaking strength.

If a specific lifting device is used for package handling then it will be designed to comply with ANSI N14.6, Special Lifting Devices for Shipping Containers Weighing 10,000 Pounds $(4,500 \mathrm{~kg}$ ) or More (ANSI 1993). The N14.6 requirements for critical loads 


\section{WHC-SP-1168 Rev. 0}

do not apply. The lifting requirements of NUREG/CR-0612, Investigations of the Performance of Solidified High-Level Nuclear Waste Forms (1979), will be applied to the structure of the lifting device to insure a factor of 6 on yield and 10 on ultimate strength.

\subsubsection{Tie-Down Devices}

Package tiedown devices will comply with 49 CFR 393, "Parts and Accessories Necessary for Safe Operation," Code of Federal Regulations, as amended. Cask tiedown attachment points will comply with 10 CFR 71.45 .

The Type B Drum package will be evaluated for the effects of tiedown loading and transport loading transmitted to the package through the tiedown system.

\subsection{OTHER NORMAL LOADING CONDITIONS}

\subsubsection{Handling Loads}

The design of the Type B Drum packaging will account for all loads associated with the handling during inner containment vessel processing, package assembly for shipment, and placement and removal from the transport vehicle. Handling loads will also include any pressure or mechanical loads that might be associated with the placement and removal of the Type B Drum contents (i.e., the 55-gal drum or 114 L [30-gal] drum.)

\subsubsection{Fabrication Loads}

The analysis of the Type B Drum will account for any loads imposed on it during the course of fabrication either from handling or from the fabrication processes (e.g., welding or heat treatment).

\subsubsection{Test Condition Loads}

The analysis of the Type B Drum will account for any loads imposed on it during the course of acceptance testing. This will include load testing and pressure testing to values in excess of the expected maxima for normal transport conditions. 


\subsubsection{External Environmental Loads}

The Type B Drum will be evaluated for the effects of external environmental loads such as corrosive materials, rod salt, rain, hail, road debris, exhaust, and any other expected conditions that might damage the package exterior.

\subsection{HYPOTHETICAL ACCIDENT CONDITIONS}

The hypothetical accident conditions are applied in sequence (9-m [30-ft] drop, 1-m [40 in.] puncture, fire, water immersion.) The effects of 9-m (30-ft) drops at different orientations (end, corner, side, and oblique) are to be considered individually (i.e., the effects of drops are not cumulative). The ambient air temperature before, during, and after the test must be within the range of $-29^{\circ} \mathrm{C}\left(-20^{\circ} \mathrm{F}\right)$ to $+38^{\circ} \mathrm{C}\left(+100^{\circ} \mathrm{F}\right)$ with the selected value the most unfavorable for the feature under consideration.

\subsubsection{Nine-Meter Free Drop}

The Type B Drum will be evaluated for a 9-m (30-ft) drop onto an essentially unyielding horizontal flat surface. Package orientation will be such that the maximum damage is imparted. Drop orientations analyzed will include end, corner, side, and oblique. The end containing the ICV and OCV closures will be evaluated, as well as the end which does not. Oblique orientations will be evaluated at $15^{\circ}$ intervals, and the worst-case angular orientation determined. Physical drop testing will include closure end, closure end corner, side, and worst case oblique angles. The ICV and OCV will be capable of separation after the 9-m (30-ft) drop in any orientation.

\subsubsection{One-Meter Puncture Drop}

The Type B Drum will be evaluated for a 1-m (40-in.) free drop onto the upper end of a solid, vertical, mild steel bar mounted on an essentially unyielding horizontal surface. The bar will be $15 \mathrm{~cm}(6 \mathrm{in}$.) in diameter, with its top edge rounded to a radius of no more than $6 \mathrm{~mm}$ (.25 in.) and having a length great enough to cause maximum damage to the package but not less than $20 \mathrm{~cm}$ ( 8 in.). The long axis of the bar will be vertical. The ICV and $\mathrm{OCV}$ will be capable of separation after the puncture drop in any orientation.

\subsubsection{Thermal}

The Type B Drum will be evaluated for total exposure for not less than 30 minutes to a heat flux not less than that of a radiation environment of $800^{\circ} \mathrm{C}\left(1475^{\circ} \mathrm{F}\right)$, with an emissivity coefficient of at least 0.9 . For purposes of calculation, the package emissivity will 
be the greater of its actual value if exposed to a fire or a value of 0.8 . Artificial cooling is not permitted and any combustible components must be allowed to extinguish naturally. Solar insolation may be disregarded before to, during, and following the fire.

\subsubsection{Water Immersion}

5.4.4.1 Immersion - Fissile Material. Water inleakage will be assumed for criticality safety calculations, and no immersion test is required.

5.4.4.2 Immersion - All Packages. This test will apply to the undamaged Type B Drum. The package will be evaluated for water pressure equivalent to immersion under a head of water at least $15-\mathrm{m}$ (50-ft) deep for a period of not less than 8 hours. For test purposes, an external pressure of water of $147 \mathrm{kPa}$ (21 psi) gauge is considered to meet these conditions.

\subsection{INTERNATIONAL ATOMIC ENERGY AGENCY CONDITIONS}

The Type B Drum will not be certified to International Atomic Energy Agency Safety Series 6 conditions; however, the deep submergence condition of Safety Series 6 will be applied.

\subsubsection{Deep Submergence}

The undamaged Type B Drum will be evaluated under the deep submergence conditions of International Atomic Energy Agency Safety Series 6 (i.e., 200-m [656-ft] depth). Inner containment integrity will be maintained under these conditions.

\subsection{STRUCTURAL DESIGN CRITERIA}

\subsection{GENERAL}

\subsubsection{Material Properties}

Metallic materials will be austenitic stainless steel except for bolting and other components where wear resistance and high strength are required. For such items, consideration will be given to fatigue, brittle fracture, and corrosion resistance. Materials that are part of the ICV or OCV containment boundary will be austenitic stainless steel which conforms to ASME Boiler and Pressure Vessel Code Sections II and III. All other materials will be to American Society for Testing and Materials specifications or equivalent. 
Nonmetallic material properties will be verified by test or certified by the manufacturer as being derived from tests. Phenolic foams will comply with DOE Material and Equipment Specification, SP-9, Revision 1, and Supplement.

\subsubsection{Analytical Procedures}

Structural analytical procedures for the containment vessels will follow NRC Regulatory Guides 7.6, Design Criteria for the Structural Analysis of Shipping Cask Containment Vessels, and 7.8, Load Combinations for the Structural Analysis of Shipping Casks for Radioactive Material (NRC 1978, 1989).

\subsection{NORMAL LOAD CONDITIONS}

\subsubsection{Containment Boundary}

Under the conditions defined in NRC Regulatory Guide 7.8, the inner and outer containment vessel containment boundaries will be analyzed following the guidance and criteria of NRC Regulatory Guide 7.6.

\subsubsection{Balance of Packaging}

The analysis methods applied to the balance of the packaging will follow sound engineering principles.

\subsection{HYPOTHETICAL ACCIDENT CONDITIONS}

\subsubsection{Containment Boundary}

Under the conditions defined in NRC Regulatory Guide 7.8, the inner and outer containment vessel containment boundaries will be analyzed following the guidance and criteria of NRC Regulatory Guide 7.6. The inner containment boundary will not yield or buckle under any of the structural hypothetical accident conditions. Containment lid joints will prevent the application of shear loads to closure bolts. 


\subsubsection{Balance of Packaging}

Bolts will have a fine thread appropriate to the diameter of the bolt. Closure bolts will be installed with a lubricant to insure proper torquing. Hard washers may be inserted between the bolt head and the closure to prevent galling. Bolts will be recessed to prevent side loads from being applied under any structural accident condition.

\subsection{EXPERIMENTAL STRESS ANALYSIS}

Experimental stress analysis or testing is permitted as a reasonable substitute for analytical methods. This may apply to any component of the Type B Drum. Computational stress analysis is required for the $9-\mathrm{m}(30-\mathrm{ft})$ drops to identify the worst-case oblique angle orientation.

\subsection{NUCLEAR DESIGN CRITERIA}

\subsection{CRITICALITY SAFETY}

The Type B Drum criticality safety classification will be determined from the details of the package design and the contents of the package when such information is available.

\subsubsection{Normal Conditions}

The Type B Drum package will be designed and analyzed in accordance with the requirements of NRC regulations in 10 CFR 71.55. For analysis purposes, subcritical will mean a reactivity, $k_{\text {eff }}$, of no more than 0.95 considering all calculational biases and uncertainties.

\subsubsection{Hypothetical Accident Conditions}

The Type B Drum package will be designed and analyzed in accordance with the requirements of NRC regulations in 10 CFR 71.55. For analysis purposes, subcritical will mean a reactivity, $k_{\text {eff }}$, of no more than 0.95 considering all calculational biases and uncertainties. The package will be considered to contain pure water at the optimum density for these calculations. 


\subsection{SHIELDING}

\subsubsection{Normal Conditions}

Package shielding will ensure that the dose rate limits of 10 CFR 71.51 and 49 CFR 173 "Shippers-General Requirements for Shipments and Packaging," Code of . Federal Regulations, Section 441, as amended, are not exceeded. The maximum surface dose rate upon any accessible surface of a loaded package will not exceed $200 \mathrm{mrem} / \mathrm{hour}$. The maximum dose rate at $1 \mathrm{~m}$ from the package boundary will not exceed $10 \mathrm{mrem} /$ hour. Dose rates will include neutron and gamma radiations, and secondary gamma radiation from neutron capture in shielding material.

\subsubsection{Hypothetical Accident Conditions}

Package shielding will ensure that the dose rate limits of 10 CFR 71.51 are not exceeded. The maximum dose rate at $1 \mathrm{~m}(3 \mathrm{ft}$ ) from the package (the surface of the Type B Drum) will not exceed 1,000 mrem/hour under hypothetical accident conditions. Dose rates will include neutron and gamma radiations and secondary gamma radiation from neutron capture in shielding material.

\subsection{CONTAINMENT}

\subsubsection{Normal Conditions}

The Type B Drum packaging will be designed such that there will be no loss of contents under the normal conditions of transport. Inner and outer containment seals will be leaktight.

\subsubsection{Hypothetical Accident Conditions}

The Type B Drum packaging will be designed such that there will be no loss of contents under the hypothetical accident conditions of transport. Inner and outer containment seals remain leaktight. 
WHC-SP-1168 Rev. 0

\subsection{HEAT MANAGEMENT}

\subsubsection{Normal Conditions}

The Type B Drum will be designed and the contents so limited as to satisfy the thermal conditions of 49 CFR 173.442 and the external surface temperature limits of 10 CFR 71.43(g). Both external and internal heat will be considered in the analysis.

\subsubsection{Accident Conditions}

The Type B Drum will be evaluated under the hypothetical accident conditions of transport. There will be no loss of containment or contents nor any reduction in nuclear criticality safety as a result of the accident thermal conditions. Both external and internal heat will be considered in the analysis.

\subsection{GAS GENERATION MITIGATION}

For operational purposes, means to mitigate pressure and hydrogen (see Section 4.5 .4 ) caused by gas generation within the package may be provided. The hydrogen getter 1,4-bis(phenylethynyl)benzene (DEB) should be considered for use. The Kansas City Division report Getter Material Products Development: DEB Hydrogen Getter Gas Inhibition Analysis (KCD 1995), demonstrates that the DEB hydrogen getter captures hydrogen gas and reduces overall pressure within packaging, even in the presence of known inhibitors. However, no credit will be taken for active gas mitigation features in the hypothetical accident scenarios.

\subsection{PACKAGE SERVICE REQUIREMENTS}

\subsection{OPERATIONAL AND TRANSPORTATION INTERFACE REQUIREMENTS}

The Type B Drum will be designed to interface with the loading and unloading conditions of DOE facilities. The Type B Drum transportation interfacing will consider the number of packages that may be shipped in a truck trailer where the gross vehicle weight is limited to 80,000 pounds (legal weight truck). Gross vehicle weight is the total weight of the loaded transporter in its over-the-road configuration. 
WHC-SP-1168 Rev. 0

Package interfacing with the transporter trailer will accommodate placement or removal by forklift or overhead crane. Tiedowns will be compatible with the structural members of the trailer.

\subsection{IN-SERVICE INSPECTION/MAINTENANCE REQUIREMENTS}

The design of the Type B Drum packaging will consider in-service inspection and maintenance.

\subsubsection{Containment Vessels}

Welds will be inspectable by radiographic testing. A means will be provided for pressure testing the inner and outer containments before each shipment and during annual maintenance and acceptance testing. The containment vessel closure seals will be replaceable. High wear components will be reasonably replaceable. Surface finish will be $64 \mathrm{rms}$ or better. Consideration will be given to decontamination by avoiding rough welds, crevices, or other surface features which might trap radioactive particulates.

\subsubsection{Balance of Package}

All welds will be inspectable by appropriate means such as dye penetrant examination, ultrasonic testing, or visual inspection. A means will be provided to perform moisture measurements and drying operations, if needed, on the contained thermal insulation/ impact protection media. Seals for weather proofing and any high wear components will be reasonably replaceable. Surface finish will be $125 \mathrm{rms}$ or better.

\subsection{MANUFACTURING REQUIREMENTS}

\subsection{CONTAINMENT VESSELS}

The inner and outer containment vessels will be manufactured in accordance with NUREG/CR-3854, Fabrication Criteria for Shipping Containers (1985), and NUREG/CR-3019, Recommended Welding Criteria For Use in the Fabrication of Shipping Containers for Radioactive Materials (1984), as applicable. 
WHC-SP-1168 Rev. 0

\subsection{BALANCE OF PACKAGE}

The balance of the package will be manufactured in accordance with NUREG/CR-3854 and NUREG/CR-3019, as applicable.

\subsection{QUALITY ASSURANCE REQUIREMENTS}

The Type B Drum will be designed, manufactured, and tested following a quality assurance plan that will be included in the safety analysis report for packaging for DOE approval. Requirements for such a quality assurance plan are contained 10 CFR 71, Subpart H.

\subsection{REFERENCES}

10 CFR 71, "Packaging and Transportation of Radioactive Materials," Code of Federal Regulations, as amended.

49 CFR 173, "Shippers-General Requirements for Shipments and Packaging," Code of Federal Regulations, as amended.

49 CFR 393, "Parts and Accessories Necessary for Safe Operation," Code of Federal Regulations, as amended, U.S. Department of Transportation, Washington, D.C.

ANSI N14.5, 1987, Radioactive Materials Leakage Tests on Packages for Shipment, American National Standards Institute, New York, New York.

ANSI N14.6, 1993, Special Lifting Devices for Shipping Containers Weighing 10,000 Pounds $(4500 \mathrm{~kg}$ ) or More for Nuclear Materials, American National Standards Institute, New York, New York.

ANSI N14.23, 1994, Design Basis for Resistance to Shock and Vibration of Radioactive Material Packages Greater than One Ton in Truck Transport, American National Standards Institute, New York, New York.

ASME, 1989, Boiler and Pressure Vessel Code, American Society of Mechanical Engineers, New York, New York. 
KCD, 1995, Getter Material Products Development: DEB Hydrogen Getter Gas Inhibition Analysis, AlliedSignal Aerospace Co.-Kansas City Division, Kansas City, Missouri.

NRC, 1978, Design Criteria for the Structural Analysis of Shipping Cask Containment Vessels, Regulatory Guide 7.6, U.S. Nuclear Regulatory Commission, Washington, D.C.

NRC, 1984, Conditions for Waste Shipping Subject to Hydrogen Gas Generation, NRC Information Notice 84-72, U.S. Nuclear Regulatory Commission, Washington, D.C.

NRC, 1989, Load Combinations for the Structural Analysis of Shipping Casks for Radioactive Material, Regulatory Guide 7.8, U.S. Nuclear Regulatory Commission, Washington, D.C.

NUREG/CR-0612, UCRL-52700, 1979, Investigations of the Performance of Solidified HighLevel Nuclear Waste Forms, Lawrence Livermore National Laboratory, Livermore, California.

NUREG/CR-3019, UCRL-53044, 1984, Recommended Welding Criteria for Use in the Fabrication of Shipping Containers for Radioactive Materials, Lawrence Livermore National Laboratory, Livermore, California.

NUREG/CR-3854, UCRL-53544, 1985, Fabrication Criteria for Shipping Containers, Lawrence Livermore National Laboratory, Livermore, California.

RFP, 1993, Backlog Residues at the DOE Rocky Flats Plant: Residue IDC Descriptions, Revision 1, U.S. Department of Energy-Rocky Flats Plant, Golden, Colorado.

Vectra, 1994, Safety Analysis Report for the TRUPACT-II Shipping Package, Revision 5, Vectra, Federal Way, Washington.

WEC, 1994a, Report on the Conceptual Design of the Unshielded Type B Drum Packaging, Westinghouse Electric Corporation-Nuclear Technology Division, Pittsburgh, Pennsylvania.

WEC, 1994b, Report on the Conceptual Design of the Shielded Type B Drum Packaging, Westinghouse Electric Corporation-Nuclear Technology Division, Pittsburgh, Pennsylvania.

WIPP, 1989, DOE/WIPP 89-004, TRUPACT-II Content Codes (TRUCON), Rev. 3, Waste Isolation Pilot Plant, Carlsbad, New Mexico. 
WHC-SP-1168 Rev. 0

This page intentionally left blank. 
WHC-SP-1168 Rev. 0

DISTRIBUTION

Number of copies

OFFSITE

2

U.S. Department of Energy.

Headquarters

19901 Germantown Road

Gaithersburg, Maryland 20874-1290

E. B. McNeil

EM-26

M. J. Conroy

EM-26

ONSITE

2

U.S. Department of Energy,

Richland Operations Office

D. W. Claussen

S7-55

RL Public Reading Room

$\mathrm{H} 2-53$

1

Pacific Northwest Laboratory

Technical Files

P8-55

17

Westinghouse Hanford Company

W. S. Edwards (10)

G2-02

R. J. Smith

G2-02

S. R. Jones

G2-02

Correspondence Control

A3-01

Central Files

L8-04

Information Release

Administration (3)

L8-07 
WHC-SP-1168 Rev. 0

This page intentionally left blank.

Distr-2 